American Journal of Applied Sciences 9 (7): 974-978, 2012

ISSN 1546-9239

(C) 2012 Science Publications

\title{
Malaysia Youth Council (MBM) and its Relevance to Youth Development
}

\author{
${ }^{1}$ Dzuhailmi Dahalan, ${ }^{1}$ Haslinda Abdullah, ${ }^{1}$ Azimi Hamzah, \\ ${ }^{1}$ Ismi Arif Ismail, ${ }^{2}$ Ezhar Tamam, ${ }^{1}$ Abdul-Lateef Abdullah, \\ ${ }^{3}$ Sarjit S. Gill, ${ }^{1}$ Nobaya Ahmad and ${ }^{1}$ Turiman Suandi \\ ${ }^{1}$ Institute for Social Science Studies, \\ Laboratory of Youth Well-Being and Social Health, \\ ${ }^{2}$ Department of Communication, \\ Faculty of Modern Language and Communication, \\ ${ }^{3}$ Deparment of Social and Development Science, \\ Faculty of Human Ecology, \\ Universiti Putra Malaysia, Malaysia
}

\begin{abstract}
Problem statement: Malaysia Youth Council (MBM) which is also known as National Youth Council is a Non-Governmental Organization (NGO) accredited to represent the voice of youth generation in Malaysia. Its' main aim is to boost and motivate youth organizations to play a positive and effective role towards society and country. However, does MBM currently being transformed holistically in the true sense as the catalyst of Malaysian youth development? Does MBM's presence being felt by youth in Malaysia completely? Approach: Data for this study were collected based on literature analysis, random observations on the scenario that happened, discussion among fellow researchers in the field of youth development and selective and informal feedback from a number of fellow practitioners that are active in youth work in Malaysia. Results: Analysis found that there are still several outdated issues that need to be resolved especially related to the weakness of the youth organizations in Malaysia, whereby this not reflect the acknowledgement of MBM as the body that fight for the youth concerns in Malaysia. Conclusion: The findings provide space for further research on issues raised from various perspectives apart from empowering Malaysian youth in the near future.
\end{abstract}

Key words: Malaysia Youth Council (MBM), championing youth, youth development, relevancy of MBM, Non-Governmental Organization (NGO)

\section{INTRODUCTION}

Youth constitute half of the Malaysian population (D'Silva et al., 2010). Continuation of nation development agenda need to involve youth as partners. Statistics from Department of Statistical Malaysia shows that in 2008, from 27.7 million people in Malaysia, 11.26 million people $(40.6 \%)$ is from youth group. Meanwhile, it is expected that in 2012, the number of youth in Malaysia will be increased to 11.65 million (40.2\%). Asnarulkhadi (2009) stated that demographically, youth is categorized as individual in age group of 15 till 40 years is significant numerically and if translated into power sources, youth is positively influential towards nation formation whether from politic aspect (voters), social (unity) and economy (human capital). Youth generation in Malaysia must be developed as homo intelligence youth which is generation of post-modern knowledge era, have high personality, smart in using knowledge for life progress and contribute to development of society and nation (Jalaluddin, 2009). As such, youth development activities should be reactive towards youth needs, focus on accentuating the potential (Azimi, 2005) so that all the earnest aspirations of the country for this generation can be accomplished.

Hope of youth development in Malaysia: Youth problem need to be approached. Reluctant to discuss on this issues would only detrimental for the country in the future. Youth who do not contribute to the country not only because loss to oneself, but also to the country as a whole. Therefore, youth development philosophy has to be clear. The goal of positive youth development is hard to be achieved if the philosophy highlighted is vague and ambiguous.

Corresponding Author: Dzuhailmi Dahalan, Institute for Social Science Studies, Laboratory of Youth Well-Being and Social Health, Universiti Putra Malaysia, Malaysia 
Delgado (2002) stated that positive youth development aim to identify youth needs and cultivate relevant competency towards producing successful adult generation. Compared to the approach of seeing youth as problematic group, positive youth approach, on the other hand, see this group as sources and develop based from their strength and ability, nurtured in their own community (Delgado, 2002).

Youth development is a process, not an event (Samsudin, 2007). Conflict on youth development always happens in term of balancing between investment of infrastructure development and individual development (Samsudin, 2007). In Malaysia, the paradigm of youth development area needs to be shifted to make Malaysia as a hub of global youth development. The setting of particular resolution related to youth development policy should be based on high impact researches other than systematic implementation. However, does the status of youth development level in Malaysia if measured from the aspect of youth involvement, programs allotments within focus group, effective cost and return on investment? Based on current scenario, answers to questions raised clearly place Malaysia far from the hope of actual youth development.

Transformation of youth development in current era: Youth represent a significant group in a society. Youth characteristics within society is able to either give hope or despair to the country. In the current era, most of the issues and social problems happened in Malaysia involved the youth. Crisis that occurs may downbeat the hope of youth development in this country.

What is actually happening to the youth generation in Malaysia these days? Do the facilities and infrastructure developed by the government all this while has prepared the sufficient opportunity to the youth generation for their rights of self-development? If been compared, why there is huge difference between contemporary youth figures and youth figures that were born during the colonization of Malaysia? Who is the 'culprit' that has killed the real potential of our youth nowadays?

Therefore, the effort of youth development in Malaysia in this era should not be done ignorantly (Aribi et al., 2007) and adhere to the interest of particular individual or group only. Old-fashioned approach that has successfully produced youth figures in the past need to be re-evaluated. This is because youth development is very sensitive to the changes of orientation within the society. Generally, society in Malaysia has changed a lot. Facility, comfort, prestige for self and family is something that becomes a priority to the society nowadays.
All parties should realize that youth in Malaysia today is a generation that is rejoicing the 'pleasure' of independence gained by the earlier generation of youth. Gaining a pleasure or benefits without struggle and effort has place the youth nowadays in 'comfortable zone'. Maybe it is not false to say that the personality of youth generation nowadays is much influenced by idols produced from entertainment either within our own country or western countries. Even there are thousands quotes within youth generation who made the noble warriors such as the Prophet a.s and others figure as their idols, but the reality which happens is that characteristics of youth nowadays seems to deny the quotes they uttered.

\section{MATERIALS AND METHODS}

This concept study was developed based on a qualitative method. It involved analysis of the literature on selective writing and research on a series of contemporary youth development in Malaysia, that was spearheaded by experts in local youth development. On top of it, further data was collected through random observations together with fellow researchers on curent issues specifically on the effectiveness of MBM in facing the challenges of youth development in Malaysia. Several selective and informal feedback on the issues pertaining to the relevance and the direction of $\mathrm{MBM}$ in the future were obtained from selected youth work practitioners.

\section{RESULTS}

The positive development of youth is an investment towards the development of each young individual. It is inclusive of the self-leadership either from thinking perspective, emotion or physical via right sources or approaches. Youth leadership quality always grabs the attention of discussion that worries many concerned parties in society.

In Malaysia, the existence of Malaysia Youth Council (MBM) as a non-governmental organization and main body that coordinate youth organizations and students illustrates how serious is the approach taken to form a youth leaderships with quality. Up to today, there are 36 national bodies and state youth councils with 4 allied bodies merged with MBM.

The existence of MBM as a main body that coordinates youth organizations under it is a huge blessing to the country and should be appreciated by youth generation in Malaysia. MBM establishment is in accordance with effort and objective of the country towards nurturing a youth generation that is able to act 
as proactive partners in development. MBM operates based on three main functions namely implementing policy and youth development programs, coordinate and organize activity, service and advocation; and act as the representative channel at various scopes and levels (Azimi et al., 2002).

Behind MBM's recognition as representing the voice of youth through its mission of operations, the wearisome syndrome that is shackling youth organizations in Malaysia also drags a controversial issue related to the relevance of MBM on this. Samsudin (2007) stated that from approximately 6000 youth associations that are registered in Malaysia, only about 3000 youth associations that are active. Statistics showed that until year 2006, Malaysia has 2445 youth associations that are active, 278 newly established youth associations, 1532 associations cancelled and 392 associations that applied to be established but had been rejected (Aribi et al., 2007).

In another related scenario, Azimi and Turiman (1997) regard that most youth associations in Malaysia are still at infant maturity level, several are in youth maturity level and only a few achieved adult maturity level. Scenario in Malaysia also showed that not more than $10 \%$ of youth generation becomes the members of youth association and moreover according to Samsudin (2007) the capacity of existing youth associations to accommodate the 11.1 million youths in Malaysia is limited.

Current scenario of leadership and management of youth association is not much different from what had happened in the year seventies ago (Azimi and Turiman, 1996). Observations on the associations show several weakness that are still happening such as lack of participation of members in association activities, conduct ad-hoc activities instead of activities based on members' desire, do not place societal agenda as a priority and only few associations have programs that are specific to produce successor leaders (Azimi and Turiman, 1996).

Azimi and Turiman (1996) stated that many youth associations have leaders or members with personal interest or personal gain such as getting the opportunity to join tour program, attending seminar or achieving certain status. This condition according to Azimi and Turiman (1996) analogically like a little baby who cries for milk, for the diaper to be changed, to be put to sleep and to be given medicine.

The question is what is the role of MBM as a main body at national level in coordinating all youth associations that merged under it? Are the efforts carried out by MBM effective enough in approaching weaker youth associations to become affiliate members? Is it not the objective of MBM establishment of the Allotment of Youth Organization and Development Act 2007; Section 49 (1) to boost and encourage youth association to play positive and effective role towards society and nation; stimulate and create relationship, cooperation, understanding and connection among youth association and youths who are balanced in various fields; and nurture responsibilities, patriotism and volunteerism among youth association?

MBM's aim is to become 'Bottom Billion' which act as People Spokesperson in whatever matters pertaining to youth at grassroots level, national and international level (MBM, 2010). However, what are the honest views of MBM on the paradigm shift of youth association in Malaysia? Does MBM idealism still fail to give the impact to majority of youth to be involved in association? Thus, considering the current scenario that restraint youth development in Malaysia, does the view that recognize MBM as representative of youth voice is a paradox? It is undeniable that MBM has produced many leadership talents that could be considered as successful in Malaysia, even so, if measured from holistic youth development, does it worth the issues and social crisis that stroke youth generation in Malaysia?

\section{DISCUSSION}

Positive youth development is an interpretation of the orientation of life in a particular society. Although there are parties that called themselves as youth development champion, however the fact is youth development itself does not need monopoly power. The question is, does the youth generation which aspired to be born by the nation is aligned with what had been emphasized by the society nowadays? For instance, does the emphasis solely on the academic achievement with ignorance on the other important aspect such as personality excellence able to accentuate youth potentials as desired by the country? Where is the value if the country has many youth groups that have decent academic achievement but at the same time have corrupt thinking and behaviors?

As life orientation in society is shaping youth generation characters, thus society role should be empowered. Even it is undeniable that the existing or youth development platform like MBM is very helpful as a body to coordinate and regulate all youth organizations, but the main issue is on whether does the youth group in Malaysia need MBM? Values that have been stressed by society today insist youth to do something that is more important to fulfill recent 
demands of life. Peremptorily, youths' demand, desire and need should be refined. Although money is not everything, but for youth group nowadays, everything needs money. Federation of Malaysian Consumer Associations (FOMCA) exposed that as many as 41 youths in Malaysia aged between 21-40 years are declared bankruptcy every day Utusan Malaysia, 2011, which is something serious and need to be handled.

In another different context, statistic shows that many Malay potential voters, especially young people are not registered as voters Utusan Malaysia, 2011 which conjure up 'horrible nightmare' to MBM as a youth body that is influential and recognized as representing the youth group in Malaysia. The ratio of 1:40 Malay voters compared to Non-Malay voters is surprising Utusan Malaysia, 2011 as if Malay youth is ignorant if power among the Malays are lost.

Research by Barisan National Youth Laboratory formulated that most young voters took the non-partisan (impartial) on nation politics Utusan Malaysia, 2011. Related cynical issue arise on how MBM interpretation of Malaysian youth perception on their existence pertaining to the issue of neglecting responsibilities to register as voters. If responsibility issue on determining future nation leadership is ignored by youth, then what is the expected perception of Malaysian youth on the leadership of MBM and its relevance in raising youth dignity? Could we say that youth is aware of MBM and its leadership in deciding the direction of youth development in Malaysia in the future?

In author's viewpoint, assessment of MBM relevance from Malaysian youth perspective should be studied. Although the objective of MBM establishment is very noble, however does the youth in Malaysia is much depends on MBM existence? According to Asnarulkhadi (2009), MBM is perceived as bound to top-down planning, whereby it has become usual practice in such planning where the purpose and method to achieve certain decision much depends to the leaders only. Also according to him, the actual needs of youth from their own perspective are only be the residual items in such significant discussion on policy formulation. Therefore, research on quo vadis MBM is to oppose or confirm pessimistic argument that see MBM as not more than a platform for potential politician leaders to be put forward for the future.

\section{CONCLUSION}

Perspective of youth development should not be viewed in a shallow context. Does someone's personality should become famous first so that the success is renowned on youth development program?
The answer is certainly no. Hence, although youth development sometimes become so subjective because of overloading of explicit and implicit discourse, but collectively it still can be measured based on the biasness scenario which occurred. Conditionally, publicity of youth development content should make equally so that objective assessment could be made. Based on argument on how complex it is to prove the investment of each individual on positive youth development, this series of youth development is broad in nature. In the context of youth leadership like MBM, sensitivity to nature, wants and needs of youth must be highlighted. Research done by Malaysia Research Institute of Youth Development found that $65 \%$ of the programs that are organized by the youth organizations are not interesting Utusan Malaysia, 2011 thus imply a message to MBM to do some transformation. Hence, MBM need to prove its relevance to the demand of a total youth development. An effective organization is an organization that is successful adapting its operation with current situation. Therefore, this study reinstates the issue on relevancy of MBM as the catalyst of youth development in Malaysia nowadays and in the future.

\section{REFERENCES}

Aribi, A.S., N.M. Sahari and H.N. Ahmad, 2007. Youth not registered under association. Malaysia Research Institute of Youth Development.

Asnarulkhadi, A.S., 2009. Emptiness of national youth policy-supporting youth potential through transformation of conflict approach. Malaysian J. Youth Studi., 1: 1-22.

Azimi, H. and S. Turiman, 1996. Issues and challenges in youth development. Pceedings of the Negeri Sembilan Youth Council Conference, Jul. 22-22.

Azimi, H. and S. Turiman, 1997. Excellent Culture in Youth Association.

Azimi, H., 2005. Helping Malaysian Youth Move Forward: Unleashing the Prime Enablers.

Azimi, H., S. Turiman and T. Ezhar, 2002. Youth organization in malaysia: development and potential enhancement. Universiti Putra Malaysia.

D'Silva, J.L., H.A.M. Shaffril, J. Uli and B.A. Samah, 2010. Socio-demography factors that influence youth attitude towards contract farming. Am. J. Applied, Sci., 7: 603-608. DOI: 10.3844/ajassp.2010.603.608

Delgado, M., 2002. New frontiers for youth development in the twenty-first century: revitalizing and broadening youth development. Columbia University Press.

Jalaluddin, A.M., 2009. Post smart city and youth development. Malaysian J. Youth Stud., 1: 43-68. 
Am. J. Applied Sci., 9 (7): 974-978, 2012

MBM, 2010. Malaysia youth council direction 20102012. Malaysia Institute for Research in Youth Development.
Samsudin, A.R., 2007. Youth development management towards formation of generation 2057. 